\title{
LAMPREY AND HERRING
}

\author{
Paul Freedman \\ YALE UnIVERSITY \\ USA
}

Date of receipt: $10^{\text {th }}$ of January, 2019

Date of acceptance: $25^{\text {th }}$ of September, 2019

\begin{abstract}
As is common to all periods and cultures, medieval Europe held certain foods in esteem and regarded others as common, even lowly. The social prestige of a particular food item depended on factors such as scarcity, exotic origins, but also actual taste. Among fish (or what were considered fish) lamprey was endowed with immense prestige, partly because when cooked it resembles beef but counts as a fish with regard to Church fasting rules. Herring was the most commonly-consumed fish, usually in salted form. Herring was widely available, but eaten by both rich and poor. The article compares the social symbolic ideas concerning lamprey and herring.
\end{abstract}

\section{KeYWORDS}

Fish, Lamprey, Herring, Lent, Social Prestige.

\section{Capitalia verba}

Piscis, Lampreda, Allec, Quadragesima, Auctoritas socialis. 
By examining the prestige attached to different sorts of fish during the Middle Ages, I hope to suggest some social that underpin the routine activity of eating. The history of food is hard to appreciate because of its ephemeral nature - no sooner is one meal finished than another has to be prepared. The restaurant kitchen is busy cooking while the detritus from a just-completed repast is being cleared away. Yet, unlike other repetitious and necessary activities, dining is delightful, or least it should be. Prince Talleyrand famously observed, "Show me another pleasure like dinner which comes every day and lasts an hour." ${ }^{1}$ Unlike other quotidian routines, eating is emotionally evocative. Beyond Marcel Proust's famous madeleine, food carries recollected meaning, even to ordinary people less sensitive than Proust was.

Unlike game or spices, which were largely reserved for the aristocracy, everyone in medieval Europe ate fish. Social distinction was thus manifested within a single food category —-salmon versus sardines; tuna versus stockfish; lamprey versus herring. Prestige was attached to large fish over small and to fresh fish over salted. The hierarchical relation between fish caught in fresh versus saltwater, however, was ambiguous. On the one hand, sea fish were harder to catch as fishing offshore required substantial equipment and investment. ${ }^{2}$ Given the difficulties of transport, fresh sea fish could be enjoyed only within a restrictive range. Salted fish such as herring, sardines or anchovies, on the other hand, were mass-market items. Tuna, large fish caught in great quantities through cooperative efforts such as the almadraba consortia in the Straits of Gibraltar, were prestigious even though sold mostly in salted form.

Piscine denizens of rivers, lakes and fishponds were not necessarily ranked lower than salt-water fish. Certain fresh-water fish like sturgeon had an exclusively upperclass consumer. Although the main axis of privilege was between salted versus fresh fish, intrinsic prestige differences meant that salted lamprey outranked fresh trout or carp. Moreover, freshwater fish do not lend themselves to being salted as readily as pelagic fish, and so these were generally sold fresh and, in that case, locally.

\section{Fish in the Religious and Literary Imagination}

In religious and literary works fish might play a macabre, supernatural role. A great sea creature swallowed Jonah; another monstrous fish attempted to devour

1. The Food Lover's Anthology: A Literary Compendium. Oxford: Bodleian Library, 2015: 117.

2. There is little reference to it in Anglo-Saxon Britain, for example. See Kowaleski, Maryanne. "The Early Documentary Evidence for the Commercialisation of the Sea Fisheries in Medieval Britain", Cod and Herring: The Archaeology and History of Medieval Sea Fishing, James H. Barrett, David C. Orton, eds. Oxford-Philadelphia: Oxbow Books, 2016: 23-41. See also Barrett, James H. "Medieval Sea Fishing, AD 500-1550: Chronology, Causes and Consequences", Cod and Herring: The Archaeology and History of Medieval Sea Fishing, James H. Barrett, David C. Orton, eds. Oxford-Philadelphia: Oxbow Books, 2016: 250-272. 
Tobias who killed it instead and used its liver, heart and gall to avoid the fate of Sara's previous seven husbands. ${ }^{3}$

A medieval literary topos involves crucially important objects thrown into the sea and later retrieved when a fish that swallowed the object is caught and opened up. The Stith Thompson index of folklore themes lists instances of lost rings or keys found miraculously in fish. ${ }^{4}$ The classic example is the story of the tyrant Polycrates of Samos in The Histories of Herodotus. Advised by the king of Egypt that his run of extraordinary good luck was likely to offend the gods, Polycrates tossed his most precious possession, an emerald signet ring, into the sea. Less than a week later, the ring was discovered in a fish considered so magnificent a specimen that the fisherman brought it to the ruler. Temporarily unable to evade the favor of fortune, Polycrates eventually died a grisly and shameful death at the hands of the Persians. ${ }^{5}$

In medieval examples, the fish is usually the vehicle for a favorable discovery. In Jocelyn of Furness' Life of St. Kentigern, the sixth-century missionary, also known as St. Mungo, came to the aid of Queen Languoreth of Strathclyde. She had imprudently given a ring to her lover. Her husband, King Riderch, came upon the young man and tore the ring from his finger, throwing it into the river Clyde. He then accused the queen of adultery and ordered her to produce the ring. She begged St. Kentigern for help and he sent a messenger to catch a fish in the river. On opening the fish, the ring was miraculously found inside and the king was forced to accept her counterfactual innocence. ${ }^{6}$

The young Gregorius, protagonist of Hartmann von Aue's romance of the same name, discovers he has unwittingly committed incest with his mother. In remorse, he has a fisherman chain him to a rock in the middle of a lake and throw the key into the water. Seventeen years later, in answer to a vision, two clerics journey to the lake and find the key in a fish they buy from the same fisherman who had bound the sinful Gregorius. The liberated holy sinner is acclaimed as Pope Gregory. ${ }^{7}$

An exemplum from fifteenth-century England tells of a fisherman who received the Eucharist but, being in a state of sin, did not swallow it but rather put it in the mouth of a fish. After ten years, he finally confessed his sin and was privileged to see the same fish swimming in his direction, carrying in its mouth the perfectly preserved Host. ${ }^{8}$

\footnotetext{
3. Tobias, 6-8.

4. Thompson, Stith. Motif-Index of Folk Literature. Bloomington: Indiana University Press, 1966: V, 87, N211.1; N211.12.

5. Herodotus. Histories: III, 42.

6. Lives of S. Ninian and S. Kentigern, Compiled in the Twelfth Century, ed. and trans. Alexander P. Forbes. Edinburgh: Edmonton and Douglas, 1874: 99-104. On Jocelin of Furness, Birkett, Helen. The Saints' Lives of Jocelin of Furness: Hagiography, Patronage and Ecclesiastical Politics. Woodbridge: Boydell and Brewer, 2010.

7. Aue, Hartmann von. Gregorius, ed. Burkhart Wachinger. Tübingen: Max Niermeyer Verlag, 2004. Thomas Mann wrote a version of this legend. Mann, Thomas. Die Erwählte. Frankfurt: S. Fischer, 1951.

8. Maraschi, Andrea. "Sympathy for the Lord. The Host and Elements of Sympathetic Magic in Late Medieval Exempla". Journal of Medieval Religious Culture, 43 (2017): 213.
} 
In Philippe de Remi's Le Roman de la Manekine, the heroine cuts off her left hand in order to prevent her lustful father from marrying her. After many vicissitudes, the hand is discovered, flawless and re-attachable, disgorged by a sturgeon caught in a Roman fountain. The sturgeon is served at a celebratory dinner at the papal palace. ${ }^{9}$ Here it was not just any fish that served as a supernatural intermediary, but a sturgeon, a canonical high-status fish by reason of its size and rarity as well as its delicate taste. Sturgeon was not a routine find and often prize specimens were presented to local rulers. In 1433 a fisherman named Jehan de Fricourt caught two sturgeons near Boulogne, an event sufficiently remarkable as to be worth a written notice. One was given to the seneschal, the other divided among a group of town office-holders. ${ }^{10}$ In the twelfth century, according to a donation by Count Ramon Berenguer of Provence, the first seasonal sturgeon caught in the Rhône had to be given to the abbot of Montmajour. ${ }^{11}$

The notion of unexpected fish contents continued to be the subject of wonder and legend after the Middle Ages, but now their significance was as religious messages and warnings. The discovery of a small book of Protestant tracts inside a cod-fish sold at the market in Cambridge in 1626 created a stir. The texts, originally written in the time of the Catholic Queen Mary (reigned 1553-1558), were circulated by this curious form of reprinting in order to undermine King Charles I and his government, widely regarded as insufficiently committed to the cause of a ecclesiastical reform. In this instance, the theme of miraculous fish and what they disclose could be mobilized to serve religious and political polemic. ${ }^{12}$

\section{Fish and Medieval Culinary Culture}

Associating particular dishes with different levels of prestige functions as a confirmation of status. Even the routine, non-banquet tables of medieval nobles and rulers were required to feature certain items such as game or spices. Pottages, root vegetables and dairy products were beneath notice. Such a calculus of social expectation is hardly unique to the Middle Ages. In Edith Wharton's novel The Age of Innocence, set in New York in the 1870s, the Newland Archers' first festive

9. Remi, Philippe de. Le Roman de la Manekine, ed. and trans. Barbara N. Sargent-Bauer. AmsterdamAtlanta: Rodopi, 1999: 562. According to a sixteenth-century treatise on the fish of Rome and its environs, sturgeon is the most noble and flavorful. Paulus Giovius. De Romanis piscibus libellus. Antwerp: Ioannem Grapheum, 1528: chapter 4, 11.

10. Clauzel-Delannoy, Isabelle. “'Le Hareng Roi': Boulogne et le marché du poisson à la fin du moyen âge", Boire et manger en pays bourguignons (XIV-XVI siècles), ed. Jean-Marie Cauchies. Neuchatel: Centre européens d'études bourguinonnes, 2007: 193.

11. Aurell, Martin. “Nécropoles et donations des comtes de la maison de Barcelone et l'Hôpital (XIIeXIIIe siècles)". Provence Historique, 45 (1995): 9, note 4.

12. On this incident, see Walsham, Alexandra. "Vox Piscis: or The Book Fish: Providence and the Uses of the Reformation Past in Caroline Cambridge". English Historical Review, 114 (1999): 574-606; Lynch, Kathleen. "Vox Piscis: Dead Men Shall Ryse Agayne". Shakespeare Studies, 27 (2000): 154-159. 
entertainment as a married couple includes a hired chef and decorated menu cards, signs of careful ostentation guaranteeing that terrapin (a small American turtle) or wild canvas-back ducks would be presented. ${ }^{13}$ These were indisputably among the most distinguished foods of the "Gilded Age" in America, the two expansive, ostentatious decades after the Civil War of 1861-1865.

Medieval cuisine can be described according to an aesthetic ordering, including at the high end the use of spices and a fondness for elaborately cooked and transformed food. Simplicity, light cooking and raw ingredients were not valued. Medieval aristocrats had a taste for sugar and vinegar (sweet and sour), a confusion (by our standards) of sweet and savory, so that sugar was by no means confined to dessert. The style of cooking was influenced by medical theories of the humors as well as Christian fasting.

Fish was the Catholic food of abstinence. Although sometimes served along with meat on days when anything was permitted, fish was conceived of as a separate and less preferable category. The genre of the "Battle of Carnival versus Lent" is based on the inferiority of fish to meat. In northern European countries that embraced the Protestant Reformation, the consumption of fish declined with the abolition of fast days. The English rulers tried to preserve Lent as a national rather than religious fast, but this effort failed to rescue the fishing industry, showing the generally unfavorable opinion of fish versus meat. ${ }^{14}$ In early modern and unreformed Spain, eating fish on days when it was not required by fasting rules was seen as suspiciously Jewish. ${ }^{15}$

The rapidity of spoilage meant that fresh fish had a high price relative not only to salted or other kinds of preserved fish, but to meat as well. Late-medieval market ordinances of papal Rome, for example, show that the price of the better sort of fish (migratory species such as salmon, shad or sturgeon) was at least twice that of meat. ${ }^{16}$ The showy hospitality of the Franklin in Chaucer's Canterbury Tales included serving "many a bream and many a luce in stuwe", fish of the type usually stocked in artificial fish-ponds, accoutrements of monastic and secular estates not available to ordinary people. ${ }^{17}$

13. Wharton, Edith. The Age of Innocence. New York: D. Appleton and Co., 1920: 31 (chapter 5), 330 (chapter 33).

14. Krondl, Michael. "Food Systems: Pepper, Herring and Beer", A Cultural History of Food in the Renaissance, Ken Albala, ed. London: Berg, 2012: 51.

15. Campbell, Jodi. At the First Table: Food and Social Identity in Early Modern Spain. Lincoln, Nebraska: University of Nebraska Press, 2017: 139.

16. Laurioux, Bruno. Gastronomie, humanisme et société à Rome au milieu du XVe siècle: Autour du De honesta voluptate de Platina. Florence: Edizione del Galluzzo, 2006: 454.

17. Chaucer, Geoffrey. "Canterbury Tales", The Poems of Geoffrey Chaucer, ed. Walter W. Skeat. London: Oxford University Press, 1962: 423, line 350. 


\section{Lamprey}

Nothing in the fish category was more prestigious in the Middle Ages than lamprey. It was thought to be a kind of eel as the lamprey is a long (up to three feet), finless, cylindrical creature, but in modern taxonomy lamprey forms a special class of jawless fish known as Hyperoartia. Its front end is a circular set of teeth and it attaches itself to prey whose blood and flesh it feeds on. Like eels and salmon, lamprey are migratory - born in rivers, moving out to sea at four or five years of age, and returning to spawn in the late winter. Once they spawn, they scatter and are not as good to eat, but just prior to spawning, they are fat and travel in shoals, making them easier to catch.

In Classical civilization, lamprey was one of a number of fish and sea creatures admired by connoisseurs. A Roman satirical commonplace was to depict an absurdly expensive and showy feast, indicative of the folly and vanity of the wealthy, usually the nouveaux-wealthy. In the last of the second series of Horace's satires, his friend Fundianus regales Horace with a description of a vulgar banquet given by "the rich Nasidienus" in honor of Horace's patron Maecenas. A lamprey "stretched out on a platter" is served with shrimp "swimming" around it and the host informs them that the lamprey loses flavor if caught after spawning and that the sauce is made with olive oil, wine from Chios, white pepper, mackerel roe and vinegar. As the company are admiring the lamprey, the fabric canopy over the table collapses, ruining the meal. The guests rush off even though the humiliated host tries to stay their flight by offering cranes, blackbirds, hares, pigeons and goose liver. ${ }^{18}$

In the third-century Deipnosophistae of Athenaeus, a group of literary gourmands devote considerable attention to fish and other sea creatures. Introducing the work, which consists of conversations over a single dinner spread out over fifteen books, Athenaeus says he will present an account of fish, their classification and uses. There follows a promise to include as well information about vegetables, animals, historians, poets, jokes and drinking cups. ${ }^{19}$ In Book IV, the grammarian Plutarch of Alexandria describes an Athenian meal featuring a whole lamprey so long that it covered the table from end to end. ${ }^{20}$

The lamprey, one of many piscine delicacies in the Graeco-Roman world, would become more prominent in the Middle Ages, occupying almost by itself the highest category of admiration. The great attraction of lamprey was that it counted as a fish for Catholic fasting purposes, but resembles meat even to the point that its texture is that of beef short-ribs or venison. This does not mean that the decline of the lamprey in the modern world is due to relaxed fasting with the end of Catholic domination. Lamprey has a wonderful taste, but is little known. Its demise as an elegant requisite is similar to that of turtle soup in Britain, or terrapin in the United

18. Horace. Satires: II, VIII.

19. Athenaeus. Deipnosophistae: I, 1.

20. Athenaeus. Deipnosophistae: IV, 136. Just before this, Plutarch mentions a conger eel that stretched out over no less than nine tables. Athenaeus. Deipnosophistae: IV, 135. 
States, once immensely prestigious dishes. It may be that the ambiguity of animals that are neither domestic mammals, game nor finned fish is perceived as unsettling.

A detailed as well as ruminative modern book on the lamprey, entitled La Lamproie, ou les eaux limoneuses de la mémoire, discusses eating, memory and forgetfulness. What was once a gourmet item well-known in all of France, is now consumed only in the Bordeaux region. The modern French lamprey is thus an almost forgotten delicacy. ${ }^{21}$ The classic Lamproie à la Bordelaise has three essential ingredients besides the lamprey: its blood, red (Bordeaux) wine, and leeks. ${ }^{22}$ A chef in Bordeaux, JeanMarie Amat, has spoken of the sense of loss and obliviousness that surrounds lamprey, a celebratory dish as late as the 1950s. Now lamprey is neglected even in Bordeaux, partly because of the forbidding image of the creature. ${ }^{23}$

Further south and west, the lamprey survives as an object of local celebration. Lamprey festivals take place in Galicia and northern Portugal around the Minho River. Of all the regions of Europe, northwest Iberia is where lamprey still has a popular purchase. Lamprey events also take place annually in Latvia and Estonia indicating some Baltic coast survival.

Although frequently mentioned in medieval and Renaissance Italian cookbooks, lamprey is absent from modern Italy. In the West of England and Wales, on the River Severn, lamprey were caught and eaten until the early twentieth century. The city of Gloucester is still obliged to furnish a lamprey pie at the monarch's coronation. It discharged that duty for Queen Elizabeth II in 1953, but the lamprey pie at her jubilee in 2013 was made, alas, with frozen American lamprey from the Great Lakes.

Like lobster and terrapin, lamprey should be kept alive until just before being cooked. In an essay entitled La lamproie ou les succulences de l'effroi, the eminent food scholar Claude Fischler links the monstrous character of the lamprey to the appropriately cruel manner in which it is traditionally prepared. ${ }^{24}$ According to French cookbooks, a lamprey must be bled to death, then sliced, and then cooked in red wine along with its own blood. Out of the transformational nature of cooking, according to Fischler, the horrible and evil is beneficially and enjoyably incorporated into our bodies. As we shall see, medieval preparations for lamprey were varied, but all required killing it at the last moment and using its blood for the sauce.

In The Count of Monte Cristo, Alexandre Dumas (an expert on cuisine) has his protagonist serve a unique meal that exemplifies the taste of the wealthy for the

21. Chapuis, Lise; Meller-Liron, Élisabeth; Rives, Caroline, eds. La lamproie, ou les eaux limoneuses de la mémoire. Cognac: Le Temps Qu'il Fait, 1994.

22. Puig, Alberto. "Questions de la Lamproie à la Bordelaise", La lamproie, ou les eaux limoneuses de la mémoire, Lise Chapuis, Élisabeth Meller-Liron, Caroline Rives, eds. Cognac: Le Temps Qu'il Fait, 1994: 55-62.

23. Sulève-Bazeille, Jean-Étienne. Le livre de la lamproie. Bordeaux: Confluences, 2007: 137-142. Restaurants of a traditional type in Bordeaux still feature lamprey, however, and it has a modest local cult status. On a recent visit, I had no trouble finding lamprey.

24. Fischler, Claude. "La Lamproie ou les succulences de l'effroi", La lamproie, ou les eaux limoneuses de la mémoire, Lise Chapuis, Élisabeth Meller-Liron, Caroline Rives, eds. Cognac: Le Temps Qu'il Fait, 1994: $11-54$. 
exotic. At what is described as an oriental feast, the Count serves fruit, birds and fish "from the four corners of the globe", but the outstanding course features are a lamprey from Lake Fusaro in Southern Italy and a sterlet (a type of sturgeon) from the Volga. Given their particular habitats, this must be the first time lamprey and sterlet have been served fresh at the same meal. Both were kept alive in casks with water and appropriate food, and, an additional extravagance, two of each were transported in case one died en route. ${ }^{25}$

The medieval understanding of lamprey was comparatively matter-of-fact when it came to the character of the creature, but with regard to health there was an intense interplay of fright and delight, even more than that posited by Fischler. Lamprey was considered humorally dangerous: cold and moist to the highest degree. Lamprey were thought to be poisonous, as were eels - after all, both resemble snakes. According to the fourteenth-century physician Maino de Manieri, the fish is dangerous even though delicious (valde periculosus quamvis sit ori saporiosus). To counteract its humoral frigid wetness, the lamprey should be killed while submerged in wine. It then needs to be cooked with plenty of spices which are humorally hot and dry. ${ }^{26}$

King Henry I of England was reputed to have died after eating lamprey in defiance of his physician's advice. Henry of Huntington says the king ate lamprey "which always disagreed with him", and one day this combination of appetite and vulnerability led to his death. ${ }^{27}$ In the Middle Ages, Nantes and not Bordeaux was the most famous center for acquiring lamprey. ${ }^{28}$ Henry I died at St. Denisle-Fermont in Normandy, not far from the probable source of the lamprey that supposedly dispatched him. Eels too were humorally dangerous, but also more literally poisonous, a medical opinion particularly strong during the Renaissance. ${ }^{29}$

Danger and gourmandise are often joined. In our day, the poisonous and potentially deadly Japanese blowfish (fugu) is the object of a sort of cult. But unlike the esoteric fugu, the medieval lamprey was in the luxury mainstream, not a peculiar niche item. As with terrapin in Gilded Age America, lamprey was de rigueur at upper-class meals

A set of 28 documents from 1375 to 1378 shows the fish consumption in the household of Mata of Armagnac, the wife of Prince Joan, son of King Pere the

25. Dumas, Alexandre. The Count of Monte Cristo. New York: Thomas V. Crowell, 1901: II, 95-97.

26. In the Neapolitan cookbook based on the work of Master Martino. Scully, Terence. The Neapolitan Recipe Collection: Cuoco Napoletano. Ann Arbor: University of Michigan Press, 2000: 171-172, also referring to Maino de Manieri.

27. Huntington, Henry of. Historia Anglorum: The History of the English People, ed. and trans. Diana E. Greenway. Oxford: Oxford University Press, 1996: 490: Comedit carnes murenarum quae semper ei nocebant. 28. Associated with Nantes in the thirteenth-century collection known as "Le Concile d'Apostoile". Crapelet, Georges A. Proverbes et dictions populaires aux XIIIe et XIV siècles. Paris: Imprimerie de Crapelet, 1831: 117-1 18. See Hyman, Mary; Hyman, Phillip. Histoire de poissons et de saveurs. Paris: Connaissance et Mémoires, 2001: 11.

29. Albala, Ken. "Fish in Renaissance Diet Theory", Fish: Food from the Waters. Proceedings of the Oxford Symposium on Food and Cookery 1997, Harlan Walker, ed. Totnes: Prospect Books, 1998: 50. 
Ceremonious of Aragon-Catalonia. ${ }^{30}$ During fasting periods, the princess had a taste for mussels, oysters and shrimp from coastal Catalonia and when she resided in inland Saragossa, river fish (notably trout). The princess requested servants, officials, and even a bishop to find for her rare and expensive fish such as lamprey and sturgeon. In one case, residing in Girona during Lent, she asked the administrator (batlle) of distant Tortosa at the southern border of Catalonia, to send her two pieces of sliced sturgeon in salt, vinegar and wine. In another letter from the same day, she solicited a whole, live lamprey from the bishop of Tortosa, to be served on Maundy Thursday, car gran pler nos en farets, she says, if he can fulfill her request. ${ }^{31}$ The princess considers the possibility that there won't be any lamprey available immediately, in which case, she askes a certain Garcia Lopez de Sessa, to send her the first he can find. The best Catalan lamprey came from the delta of the Ebro and great efforts were made to bring fresh or salted lamprey from there to inland markets.

The passion for lamprey could lead to follies of expenditure, as with white truffles or Montrachet in our time. In his cookbook entitled On Right Pleasure and Good Health, the fifteenth-century papal librarian Platina considered the normal price of a whole lamprey to be 5 to 7 gold aurei, but it could go for as high as 20 aurei, bid up by gluttonous and arrogant aristocrats of the papal court. ${ }^{32}$ The lords of Berkeley castle routinely sent lamprey as gifts to the English kings in the fourteenth century. In 1367, for example, the fourth lord of Berkeley furnished Edward III with six lamprey, the first of the season. Their value was extraordinary, £6 7s $2 \mathrm{~d}$, and transport cost an additional 6s 8d. Six lamprey sent to the abbot of Glastonbury at around the same time, valued at $£ 111 \mathrm{~s} 6 \mathrm{~d}$, were still costly, but not unreasonable. ${ }^{33}$

The Catalan didactic moralist Francesc Eiximenis tells a story involving lamprey that is supposed to show that eating luxurious food is not in itself sinful, as opposed to savoring and boasting. Saint Louis, king of France, invited Saint Bonaventura (like Eiximenis, a Franciscan) to dinner.

Deus saber que sent Luys, rey de França, convidà a frare Bonaventura, general dels frares menors. E aprés taula, temptant-lo e volent saber què diria, dix-li, a part. axí: -Frare Bonaventura, gran consciècia deuriets haver, car havets menjada en taula mia lampresa, que valia un franch d'aur. Cert, açò no és menjar de frare pobre- Respós frare Bonaventura, e dix-li axí:-Senyor, hom pobre no deu examinar què li és dat; mas de qualque cosa que li sia dada, deu, sens qüestións, menjar humilment per amor de Déu. Si m'haguéssets dada una sardina salada, axí matex la m'hagera menjada alegrament com la lampresa, car yo no deig fer trialles ne qüestions en ço qui.m és dat per amor de Déu-. De la qual resposta sant Luis fo fort hedifficat.

30. Trenchs, Josep. “El peix a la taula de la princesa Mata d'Armanyac: els capritxos i gustos d'una infanta", Actes del Ier Col-loqui de l'història de l'alimentació a la Corona d'Aragó. Lleida: Institut d'Estudis Ilerdencs, 1995: 309-328.

31. "and you will give us great pleasure". Trenchs, Josep. "El peix a la taula...": 325.

32. Platina. Platina's On Right Pleasure and Good Health: A Renaissance Gentleman's Discourse on Food, Health, and the Physical Pleasures, ed. and trans. Mary Ella Milham. Ashville: Pegasus Press, 1999: 209.

33. For this information I am grateful to Dr. Rowena E. Archer, Fellow of Brasenose College, Oxford. 
Eiximenis tells us that the king found St. Bonaventure's response quite edifying. ${ }^{34}$ No other source mentions this story, and indeed the jocular materialism of the king in the Eiximenis exemplum doesn't sound like the self-abasing Saint Louis of French legends. More typically, his biographer Guillaume de Saint-Pathus says Louis IX seldom ate the large and costly fish brought to table but preferred to dine on seafood pottage, giving the showy fish to charity. ${ }^{35}$

A proverb of the Gironde region states, le pauvre n'a jamais mangé de bonnes lamproies. ${ }^{36}$ That social exclusivity is an aspect of the lamprey's former gastronomic reputation. Rarity, high cost and prestige are related. When black pepper started to be affordable and widely available in fifteenth-century Europe, it became identified with ordinary people, even rustics, and so lost its place in the court cookbooks of the era in preference to spices such as nutmeg or cloves that retained their aura of exclusivity and high price. ${ }^{37}$

\section{Herring}

Herring would seem to be at the opposite end of the fish prestige spectrum from lamprey, but the comparison is not quite so binary or simple. ${ }^{38}$ Herring was not avoided by the wealthy in the way that gruel, leeks or cheese were. The mark of distinction was being able to eat other fish besides herring during fasting seasons, so monotony rather than a specific food item was the sign of low status.

Certain foods (chicken is another example) were eaten in the Middle Ages by upper as well as lower classes - democratic comestibles that transcended social symbolism. ${ }^{39}$ The bishop of Hereford bought 31,000 herring in 1289-1290 while staying at Bromholm Priory. Of a successor's total food expenditures in 1415-1416,

\footnotetext{
34. "You should know that Saint Louis, king of France, invited Brother Bonaventure, general of the Friars Minor to dine with him. And as the meal was cleared away, tempting and wanting to know what he would say, the king addressed him in this way: - Brother Bonaventure, you should be aware that you have just eaten lamprey at my table, valued at one gold franc. Does that seem like food appropriate to a poor friar? - Bonaventure responded, and spoke to him thus: - Sire, a poor brother should not examine what he has been served, but rather eat it humbly, whatever it is, for the love of God. I would as happily eaten a salted sardine if you had given one to me as that lamprey, because I don't need to investigate what is given me for the love of God-. Saint Louis was edified by this response." Eiximenis, Francesc. Terç del Crestià. Barcelona: Barcino, 1932: III, 239.

35. Saint-Pathus, Guillaume de. Vie de Louis IX, ed. H. François Delabordé. Paris: Alphonse Picard \& Fils, 1899: 120 .

36. "The poor man has never eaten good lampreys". Puig, Alberto. "Questions de la lamproie...": 60.

37. Freedman, Paul. Out of the East: Spices and the Medieval Imagination. New Haven: Yale University Press, 2008: 43 .

38. A convenient survey of herring information and history is given by Hunt, Kathy. Herring: A Global History. London: Reaktion, 2017.

39. Schubert, Ernst. Essen und trinken im Mittelalter. Darmstadt: Wissenschaftliche Buchgesellschaft, 2006: 134: Neben dem Huhn ist der Hering das einzige Nahrungsmittel, das Hoch and Niedrig gleichmaßen schätzen und verehren.
} 
seventeen per cent were for herring. ${ }^{40}$ The queen of Denmark, the archbishop of Mainz and the Landgraf of Hesse dined frequently on herring at the end of the Middle Ages, just as did the inmates of almshouses and hospitals. ${ }^{41}$ Maitre Chiquart, among the most lavish of late-medieval chefs, included herring as a separate dish, served with mustard, at a fasting-day banquet for the wedding of Count Amadeus of Savoy with Mary of Burgundy in $1403 .{ }^{42}$ In northern Europe herring was the most commonly consumed fish, especially in Lent, although certain places might have the advantage of proximity to sources for other foods considered fish. At King's College, Cambridge, during the fifteenth century, eels from the nearby Fens were more commonly eaten than any other (so-called) fish. ${ }^{43}$

Herring was plentiful, cheap and tasty enough so that it was regarded, if not as a delicacy, at least as something to be anticipated with pleasure despite its routine nature. A northwestern French poem, the Life of St. Herring, follows the fish's martyrdom from the English Channel where he was seized by forty tyrants (i.e. a boatload of fishermen), and put through tortures more painful than those suffered by St. Lawrence on his gridiron. His body was brought to the port of Dieppe, and there in a tavern, roasted on a grill (not unlike St. Lawrence) and enjoyed with garlic. ${ }^{44}$

For northern Europe, herring was particularly associated with Lent. An English victory at Rouvrey in 1429 during the Hundred Years' War is known as the Battle of the Herrings because the French forces tried to intercept a convey of weapons and barrels of herring. The latter were necessary preparations for the Lenten season which was to start soon after the battle date, February 12. During the fasting season, everyone ate herring and so, as stated earlier, the disadvantage for the less affluent classes was the inevitability of herring. At the leprosarium of Grand-Beaulieu in Chartres during ordinary times, inmates received meat three times a week and soup four times for their principle meal. In Lent and Advent, however they had only herring, very occasionally varied with some other salted fish. ${ }^{45}$

Dietary tedium provoked ceremonies of joyous humiliation of herring and other common fish to mark the conclusion of Lent. At Saint-Rémy, a Maundy Thursday procession included clerics dragging smoked herrings on strings. Each man tried to protect his herring while attempting to step on the one drawn by the person

40. Saul, Anthony. "The Herring Industry at Great Yarmouth c. 1280-1400". Norfolk Archaeology, 38 (1981): 33 .

41. Kristiansen, Mette Svart. "Fish for Peasants and Kings-A Danish Perspective", Processing, Storage, Distribution of Food: Food in the Medieval Rural Environment. Turnhout: Brepols, 2007: 214.

42. Scully, Terence. The Art of Cookery in the Middle Ages. Woodbridge-Rochester: Boydell and Brewer, 1995: 125.

43. Soyer, François. “Dining at King's College in the Fifteenth Century". Petits Propos Culinaires, 83 (2007): 51 .

44. Poem edited in Clauzel-Delannoy, Isabelle. “Le Hareng Roi'...": 198.

45. Laurioux, Bruno. Manger au moyen âge: pratiques et discours alimentaires en Europe aux XIVe et XVe siècles. Paris: Hachette, 2002: 110. 
in front of him. ${ }^{46}$ More widespread, throughout Spain, was the Carnival "burial of the sardine", a celebration before the dreary routine of fish in Lent began. It is the subject of a well-known painting by Goya, El Entierro de la Sardina, in the Real Academia de Bellas Artes de San Fernando in Madrid. ${ }^{47}$

An English schoolboy in the fifteenth century left a private notebook in which he complains about his Lenten diet of salted herring, claiming that it has increased his phlegm and made him congested. He yearns for the end of fasting and the return of the time of meat. He actually did have access to river or lake fish but longed to live near the coast: "Would to God I were one of the dwellers by the seaside, for there fish is plentiful and I like it better than I do this freshwater fish of ours, but now I must eat freshwater fish whether I like it or not." 48

Herring was the most common edible fish in the Middle Ages, with sardines and anchovies (also generally salted) as Mediterranean runner-ups. Herring was eaten in southern Europe more than sardines in the North. The infanta Mata of Armagnac, whom we have seen as an aficionada of sturgeon and lamprey, also purchased salted herring. ${ }^{49}$ At Chambéry during Lent of 1417, 20,000 salted herrings were consumed, this in a town closer to the Mediterranean than to the North Sea. ${ }^{50}$

In both northern and Mediterranean Europe, however, the greatest competitor of herring was neither anchovies or sardines but cod. Like herring, cod can be salted, but as a white and less oily fish it is easier to preserve. Unlike herring, cod can be air-dried and in this form, what is known as stockfish, it was commercialized in northern Norway as far back as the twelfth century. ${ }^{51}$ The golden age of stockfish was from after the Black Death until the Reformation which not only lowered fish consumption in Protestant territories but coincided with changing tastes. ${ }^{52}$ Some of the late-medieval and early-modern cod trade was redirected to salt cod (bacalao) which required more processing infrastructure than dried cod, but which had particular appeal in the Mediterranean. To this day salt cod, now mostly imported from Iceland, is consumed in considerable quantities in Spain, Portugal and Italy,

46. Henisch, Bridget Ann. Fast and Feast: Food in Medieval Society. University Park: Pennsylvania State University Press, 1976: 41.

47. "Entierro de la sardina". Fundación Goya en Aragón. 9 September $2019<$ https://fundaciongoyaenaragon. es/eng/obra/el-entierro-de-la-sardina/467>. I thank my Yale University colleague Carlos Eire for this reference.

48. Cited in Henisch, Bridget Ann. Fast and Feast...: 40, 43.

49. Trenchs, Josep. "El peix a la taula...": 312, 327.

50. Scully, Terence. The Art of Cookery...: 74.

51. Nielssen, Alf Ragnar. "Early Commercial Fisheries and the Interplay Among Farm, Fishing Station and Fishing Village in Northern Norway", Cod and Herring: The Archaeology and History of Medieval Sea Fishing, James H. Barrett, David C. Orton, eds. Oxford-Philadelphia: Oxbow Books, 2016: 42-49; Nedvitne, Arnved. "The Development of the Norwegian Long-Distance Stockfish Trade", Cod and Herring: The Archaeology and History of Medieval Sea Fishing, James H. Barrett, David C. Orton, eds. Oxford-Philadelphia: Oxbow Books, 2016: 50-59.

52. See Locker, Alison M. “The Decline in the Consumption of Stored Cod and Herring in Post-Medieval and Early Industrialised England: A Change in Food Culture", Cod and Herring: The Archaeology and History of Medieval Sea Fishing, James H. Barrett, David C. Orton, eds. Oxford-Philadelphia: Oxbow Books, 2016: 100-107. 
while stockfish from Norway, now almost unknown in Europe, is a staple in West Africa.

Oily fish with dark flesh, such as herring or sardines, require immense quantities of salt to preserve as opposed to "white" fish such as cod or hake. Cod has only $0.3 \%$ fat and when air-dried, it can last up to seven years without spoilage. Herring has a $15 \%$ fat content and so becomes rancid too quickly for it to be air-dried and requires more radical preservation treatment. ${ }^{53}$

Herring were caught in the fall. The season at the English port of Yarmouth affected such things as marriages, which tended to take place near Christmas when the herring fleet had returned to port. ${ }^{54}$ Herring to be consumed in Lent were gutted, rubbed with salt and then layered in barrels with salt or brine. In addition to these "white herring", as they were called, a lesser number were briefly sun dried and then smoked ("dried herring"), or cured over wood fires for between seven and 28 days ("red herring"). The British breakfast "kipper", first developed in the 1840s, is the modern descendant of red herring. ${ }^{55}$ Smoked herring required elaborate preparation: before being smoked over beech or oak wood fires for between eight and eighteen hours, the herring had to be soaked in brine for eight to ten days, desalted in fresh water for two days, drained and dried..$^{56}$

The advantage of herring over cod was that it could be caught near the shore and once treated, was easy to cook. Red herring can be eaten without any further preparation, and salted herring requires only a rinse-off. Stockfish, on the other hand, is so stiff that it must be broken into pieces with a hammer before soaking, and bacalao needs several days of soaking and multiple changes of water before it is fit to cook.

In the fourteenth century, herring runs in the North Sea were so large and the fish so crowded together that stories circulated about boats not being able to steer through the teeming water. Coordination of the seemingly inexhaustible herring from the North Sea with equally plentiful salt from Lüneburg made it feasible to commercialize a highly perishable product. Salt is widely distributed and can be obtained from inland mines or seaside salt-flats, but it is not present everywhere and often has to be imported. For the herring industry, much depends on the purity of the salt and the size of the grains. If the grains are too fine, the water is removed so rapidly that the surface tissue hardens and coagulates, resulting paradoxically in

53. Ferreira Priegue, Elisa. "Pesca y economía regional en Galicia", La pesca en la edad media. Madrid: Sociedad Española de Estudios Medievales, 2009: 12; Locker, Alison M. "The Decline in the Consumption...": 99-100.

54. Kowaleski, Maryanne. "The Seasonality of Fishing in Medieval Britain", Ecologies and Economies in Medieval and Early Modern Europe: Studies in Environmental History for Richard C. Hoffmann, Scott G. Bruce, ed. Leiden: Brill, 2010: 118.

55. Saul, Anthony. "The Herring Industry...": 35. The kipper is split down the back, brined and then smoked briefly, see Hunt, Kathy. Herring...: 55-56.

56. Benito i Monclús, Pere. "Food Systems", A Cultural History of Food in the Medieval Age, Massimo Montanari, ed. London: Berg, 2012: 51. 
incomplete moisture elimination. Grains that are too large penetrate the fish too slowly, leading to spoilage. ${ }^{57}$

Salt is a heavy commodity and unpleasant to handle, but a human necessity. The proximity of salt springs and mines to the herring fisheries was a fortuitous circumstance that encouraged formation of the Hanseatic League whose capital Lübeck around 1400 annually imported and re-sold 40-50,000 tons of salted herring. ${ }^{58}$

As with the fortunes of the League itself, the herring trade is an example of prosperous expansion in the late fourteenth century, otherwise regarded as a period of disaster and contraction. Fishing had been previously an individual activity, only haphazardly coordinated with preserving and marketing. At the end of the Middle Ages, and in Holland rather than in Scandinavia or Germany, fishermen themselves began salting and selling the herring they caught, converting their boats into salting factories so that the fish were immediately treated rather than deteriorating en route to a separate salting facility. Moreover, the Dutch found it cheaper and more secure to rely on French salt flats adjacent to the Atlantic rather on Lüneburg, and they developed ways of combining light smoking with salting which produced a more reliable and tastier fish than the purely salted variety. ${ }^{59}$

In the period of Hanseatic domination, however, fishermen devoted themselves entirely to the catch and middlemen on the shore took care of salting, transport and sale. There were different standards depending both on where the herring was caught, how much and what kind of salt was used and the reputation of the packers and conservers. In Denmark, for example, herring from the Øresund strait between Seeland (Copenhagen) and Scania (Malmö) were reputed significantly better than those caught in the Limfjord region of northern Jutland..$^{60}$ The Hanseatic authorities regulated the packing and grading of salted herring in a more rigorous way than what was practiced at lesser centers such as along the East Anglian coast of England, ${ }^{61}$ but, as with fish generally, the variation of quality was a problem for consumers, depending as it did on differentiated skills and expense with regard to preservation techniques.

Thus although herring were plentiful, to get them to consumers was as hard as it was to deliver live lamprey to court and aristocratic kitchens - the difference was that the economies of scale were such that herring were both cheap and profitable.

57. Curtis, Robert I. "Ancient Processed Fish Products", The Inland Seas: Towards an Ecohistory of the Mediterranean and Black Sea, Tønnes Bekker-Nielsen, Ruthy Gertwagen, eds. Stuttgart: Franz Steiner Verlag, 2016: 164.

58. Kristiansen, Mette Svart. "Fish for Peasants and Kings...": 215. In general, Jahnke, Carsten. “The Baltic Trade", A Companion to the Hanseatic League, Donald J. Harreld, ed. Leiden: Brill, 2015: 210-214, 256.

59. Ferreira Priegue, Elisa. "Pesca y economía...": 16-17.

60. Kristiansen, Mette Svart. "Fish for Peasants and Kings...": 213-215.

61. Saul, Anthony. "The Herring Industry...": 40. 


\section{Seasonality}

Prestige is not simply a matter of rarity. If that was the case, then beer would have been as sought after in the medieval Mediterranean as wine was in the north. There has to be a taste preference - medieval upper classes really did like piquant cuisine and were not just seduced by the fact that spices were expensive and esoteric. One way of looking at culinary perception is through fish which had clear times of scarcity and plenty depending on location and species, but also for which there were strong opinions when they tasted best apart from mere availability. Seasonality and gourmandise were complementary rather than, as with hot-house peaches or pineapples in ancien regime Europe, completely opposed.

The season for migratory lamprey was the late winter and early spring, depending on location, usually well-timed for Lent. ${ }^{62}$ North-Sea herring tended to be plentiful in late summer and early fall with the principal salting activity and selling taking place in autumn, but in the English Channel off Boulogne, the first herring weren't caught until around the time of the Feast of Saint Martin, November $11 .{ }^{63}$

Fish seasons were carefully noted in a number of medieval sources. More attention was paid than was the case with produce or even game as to when the fish were best, not just when they were available. A short German disquisition on the seasons for fish was included as part of the supplementary material for a tract entitled Wie man fisch und vögel fahren soll. This was printed in Heidelberg in 1493, but the seasonal list dates from earlier, probably the mid-fifteenth century. On the basis of the fish described, Richard Hoffmann has located the author's ecosystem as that of the upper Rhine and its tributaries from Baden to the Palatinate. ${ }^{64}$ Of the twenty-eight species, most are at their best in April and May, including brook lamprey (lemfrid), but carp, among the most important river fish, are considered of poor quality in May or June because that is when they spawn. Bitterling (a very small bottom-dwelling fish) reaches its peak in autumn. It should be emphasized that the list is not about when the fish are most plentiful, but when they taste best.

A Dutch cookbook printed in 1560 also specifies when fish are best to eat and serve. It is for the most part based on a southern German cookbook whose determinations resemble those of the seasonal tract from the 1493 Heidelberg book. Most of the fish is plentiful in the spring and summer, but bream and mackerel have excellent flavor in February and March, while lamprey is to be eaten in May, salmon in April and May. Eels have a slightly longer season; they are good from May until the middle of August. Only a few fish are said to be outstanding in the winter, including roach and perch. Here again, we are dealing with taste discrimination more than availability; human cultural preferences rather than nature. ${ }^{65}$

62. The season for river or "brook" lamprey was later, the month of May.

63. Clauzel-Delannoy, Isabelle. "Le Hareng Roi'...": 193.

64. Hoffmann, Richard C. Fishers' Craft and Lettered Art: Tracts on Fishing at the End of the Middle Ages. Toronto: University of Toronto Press, 1997: 93-95 (edition of the Seasons Tract), 40-43 (discussion).

65. Vorselman, Gerardus. Eenen nyeuwen coock boeck: Kookboek samengesteld door Gheeraert Vorselman en gedrukt te Antwerpen in 1560, ed. Elly Cockx-Indestege. Wiesbaden: G. Pressler, 1971: 140-141. On this 
Climate and habitat differences explain why, in contrast to the Dutch manual, the Catalan Libre del coch from ca. 1500 states that lamprey should be eaten in January. The Libre recommends the fall for salmon rather than the spring as in northern cookbooks. ${ }^{66}$ Another Catalan cookbook, the mid-fourteenth century Llibre d'aparellar de menjar, includes a list of twenty fish and the time of the year in which they are "most noble". There is greater variation than with the German and Dutch examples and all of the fish are saltwater species. Grouper is good in June and July, but dorada and grey mullet are best in the fall. Sardines have two seasons, May and August. ${ }^{67}$

A third Catalan collection, the Llibre de totes maneres de potatges, dating from the mid-fifteenth century, lists 72 fish, but a specific temporal period is given for only 24 of them. Here again there is considerable divergence from the northern European calendar. Mackerel, for example, are best eaten in summer and of poor quality in late winter. ${ }^{68}$

The discourse of gourmandise, that is, quality discrimination, reflected seasonal availability, medical teachings, the restrictions of the church calendar and a consensus of aesthetic opinion. A detailed compendium of such opinions is provided by the cookbook section of the Ménagier de Paris, a book of household instruction completed in the last decade of the fourteenth century. The anonymous author was a man of wealth, but not a noble and so his taste in food, revealed in more than 400 recipes, is that of someone outside the rarefied circle of the court who reflects the outlook of the bourgeoisie and petty knighthood. ${ }^{69}$ The author of the Ménagier distinguished two basic seasons, summer and winter, but gave a month-by-month list of what was being sold in the markets.

Most of the calendar is organized by availability, but there are other factors, such as health teachings, to consider as well. ${ }^{70}$ In the cold months, one should serve strongly spiced sauces that have been boiled, but in summer they should not be boiled and only mildly spiced. Vinegar should replace wine in summer as it is by nature humorally cold whereas wine is hot. The summer is also the time for small game, such as rabbits and hares, along with young domestic animals such as lambs and piglets. Doves and mallard ducks are appropriate for winter. The Ménagier offers a list of foods for Lent, not just fish but a surprising number of vegetable recipes in comparison with court cookbooks that eschew vegetables. Spinach, peas, leeks, cabbage, Brussels sprouts are all mentioned.

passage see Winter, Johanna Maria van. Spices and Comfits: Collected Papers on Medieval Food. Totnes: Prospect Books, 2007: 285.

66. Mestre Robert. Libre del coc, ed. Veronika Leimgruber. Barcelona: Curial Edicions, 1977: 100-101.

67. Llibre d'aparellar de menjar, ed. Joan Santanach. Barcelona: Barcino, 2015: 262-265.

68. Llibre de totes maneres de potatges. Barcelona: Editorial Barcino, 2017: 205-310.

69. Le Ménagier de Paris, ed. Georgina E. Brereton, Janet M. Ferrier. Oxford: Oxford University Press, 1981.

70. What follows is based on Scully, Terence. "Les saisons alimentaires du Menagier de Paris", Du manuscrit à la table: Essais sur la cuisine au Moyen Age, Carole Lambert, ed. Paris-Montréal: Champion-Slatkine-Les Presses de l’Université de Montréal, 1992: 205-213. 
Ray is available in September, but better in October. White trout are best in winter but can be obtained at other times of the year. ${ }^{71}$ Thus gastronomic considerations of taste are related to seasonal availability, but within that period there are variations of quality. The author of the Ménagier advises that one should eat round fish in winter and flat fish in summer for reasons that he doesn't explain, but it may be that round fish are the oily, fat fish such as herring, described earlier, while flat fish are the "white" fish that are easier to deal with in warm weather.

\section{The Aesthetics of Consumption and Social Privilege}

In keeping with its higher status, the lamprey was the object of many more recipes than the herring in medieval cookbooks. The majority of the 150 or so surviving cookbooks from the thirteenth through fifteenth centuries reflect the menus and tastes of royal and aristocratic courts. Among the most famous are the text known as the Viandier, attributed to the late fourteenth century French royal chef Taillevent (who probably added to an already-existing collection); the English Forme of Curry, related to the court of Richard II, and the aforementioned Libre del coc, a Catalan compendium put together for the Aragonese King of Naples. As already indicated, the Ménagier recipes, although influenced by the Viandier, reflect affluent but not aristocratic tastes and resources. The author presents instructions for spit-roasted, boiled as well as braised lamprey, but rejects certain other luxury dishes such as gilded or colored stuffed chickens, which he says are too elaborate for a knight or bourgeois. ${ }^{72}$

There were several basic recipes for lamprey in the Middle Ages. Cookbooks agree that the animal should be killed in red wine which, humorally hot and dry, is an effective counter to the cold and moist properties of lampreys. Chefs agree that the blood is the basis for an appropriate complementary sauce. "Do not waste its blood, because its sauce is made with it", the Neapolitan cookbook instructs, adding that if the lamprey is roasted on a spit rather than being slowly simmered on hot coals, something should be placed underneath to catch the blood "for that is its goodness." ${ }^{\prime 3}$ The author of the Ménagier presents a grisly and detailed description of bleeding a lamprey. If you get too much blood on your hands in the process, wash them with vinegar, but let the vinegar and blood mixture drip from your fingers into the dish rather than wasting any of this precious fluid. ${ }^{74}$

Another standard lamprey preparation was as a galantine, a cold, slightly jellied sauce. Here, according to the Viandier, the lamprey should be cooked in water, wine and vinegar. While the cooked lamprey cools, wrapped in a cloth, burnt toast is

71. Scully, Terence. “Les saisons alimentaires...": 211-212.

72. The Good Wife's Guide: Le Ménagier de Paris: A Medieval Household Book, trans. Gina L. Greco, Christine M. Rose. Ithaca: Cornell University Press, 2009: 304-305, 338.

73. Scully, Terence. The Neapolitan Recipe Collection...: 88.

74. The Good Wife's Guide...: 304. 
steeped in bouillon and then the strained residue is cooked with the blood of the lamprey. Ginger, cassia, cloves, grains of paradise, nutmegs and long pepper are added to the wet toast and reserved bouillon and this forms a gelatinous surrounding for the lamprey. ${ }^{75}$ If the lamprey is left whole, several recipes call for a nutmeg to be put into its mouth and cloves in the small orifices around its head. Master Martino of Como, writing in the fifteenth century, recommends cooking lampreys in oil, white wine and verjuice (the tart liquid of crushed unripe grapes) and serving them with a sauce made of toasted almonds or hazelnuts pounded in a mortar with toast, raisins, wine, cinnamon, ginger, cloves and the lamprey's blood..$^{76}$ The Ménagier suggests a similar sauce which turns out black and moderately thick. ${ }^{77}$ In addition to being simmered, spit-roasted or formed in a galantine, lamprey could be made into tarts or pies.

Herring was much more common and eaten more often than lamprey, but the upper-class cookbooks that have come down to us do not extensively treat this fish. In a section on "unboiled sauces", the Viandier offers a recipe for a garlic sauce to be served with fresh herring. The garlic was peeled, but its skin was steeped along with the mashed cloves in must (very lightly fermented grape juice) or verjuice to which the herring heads were added. ${ }^{78}$

As previously remarked, herring was usually salted, smoked or dried, but the aristocratic class preferred fresh to salt fish whenever possible. A bit more elaborate, and still involving fresh fish, is an English recipe for stewed herring, stuffed with its own roe along with herbs, onion, pepper, sugar, currants and bread and cooked in a mixture of ale, mustard and large raisins. ${ }^{79}$

There was a standard international repertoire of recipes. Lamprey, meat galantines, rissoles or blancmanges, appears in most medieval cookbooks. The variations were in part the result of environmental considerations, so that Mediterranean cookbooks obviously involve Mediterranean fish. With all ingredients, even basic foodstuffs, the cookbooks demonstrate regional preferences. South German cookbooks, for example, show an unusual fondness for the grain millet. The author of the Ménagier observes variations in cooking styles related to taste: Germans dislike the French habit of under-cooking carp and regard it as not only unpleasant but dangerous. ${ }^{80}$

Elsewhere I have discussed another exemplum from Eiximenis, concerning a gluttonous priest who complains to his doctor because he has lost his appetite. ${ }^{81}$ The cleric describes his dietary regimen and it quickly becomes clear that the reason

75. Tirel, Guillaume. The Viandier of Taillevent: An Edition of all Extant Manuscripts, ed. Terence Scully. Ottawa: Ottawa University Press, 1988: 132-134.

76. Martino of Como. The Art of Cooking. The First Modern Cookery Book, ed. Luigi Ballerini, trans. Jeremy Parzen. Berkeley-Los Angeles: University of California Press, 2005: 105.

77. The Good Wife's Guide...: 304.

78. Tirel, Guillaume. The Viandier of Taillevent...: 222-223.

79. Hieatt, Constance B. The Culinary Recipes of Medieval England. Totnes: Prospect Books, 2013: 66.

80. As noted in Hyman, Mary; Hyman, Phillip. Histoire de poissons...: 13.

81. Eiximenis, Francesc. Lo Crestià, ed. Albert Hauf i Valls. Barcelona: Edicions 62, 1983: 142-145. I have discussed this exemplum in Freedman, Paul. "Medieval Clichés of Health and Diet According to Francesc 
his appetite is flagging is because he is eating absurd quantities of food. The priest is sufficiently debauched in his gourmandise that he doesn't observe Lent or other fasting periods. Depraved though he is, Eiximenis' priest reflects fashionable opinion about what sorts of things people of high status prized: spices, game and sweet medicinal delicacies, although no lamprey or any other fish is mentioned.

The Rabelaisian meals of another greedy cleric are detailed in the second part of Antoine de la Salle's Jehan de Saintré, a mid-fifteenth century romance about a knight's education. ${ }^{82}$ The abbé is taken to task by a female companion for his luxurious entertainments during Lent, which include rich food and fine wines, but sometimes he does observe the letter if not the spirit of fasting regulations. On one occasion, he dines on three preparations of lamprey: roasted, in pies and served with "their sauce" (presumably made with their own blood). This meal also includes different presentations of salmon and sole along with carp, eels, red mullet, salad, dried fruit and flans. Herring is not mentioned.

Yet another clerical gourmand appears in one of the moral novelle of the fifteenthcentury Italian writer Gentile Sermini. The priest Meoccio d'Acquapendente is so captivated with fine food that he pretends to read his breviary while actually perusing a recipe book. He convinces his flock to donate their finest produce to the altar of his church, promising them hundredfold rewards in paradise. He receives a 10-pound eel that gets cut in chunks and roasted on a spit while basted with vinegar, spices, and rosemary. Finally, the eel is placed in aspic topped with pomegranate juice, oranges and spices. True, this is not a lamprey, but the size of the eel makes it special and an appropriately comic example of clerical excess. ${ }^{83}$

\section{Conclusions}

There is to this day a prestige hierarchy for fish in France. Turbot ruled the waves in the early nineteenth century, the time of Carême and Grimod de la Raynière, when grosses pièces (big pieces) of meat and fish were esteemed. Later, in the early and mid-twentieth century, the gastronomic authority who called himself as Curnonsky (cur non - Latin for "why not?"), singled out sole as the queen of saltwater fish, and bass as the king. Limandes (common dabs) were maids of honor and mulet (mullet) a page bien sympathique (a likable page) ${ }^{84}$ He doesn't here mention fresh-

\footnotetext{
Eiximenis", Sociedad y memoria en la edad media: Estudios en homenaje de Nilda Guglielmi, Ariel Guiance, Pablo Ubierna, coords. Buenos Aires: Consejo Nacional de Investigaciones Científicas, 2005: 127-134.

82. Szkilnik, Michelle. "Nourriture et blasons dans Jehan de Saintré d'Antoine de la Salle (1456)". FifteenthCentury Studies, 26 (2000): 183-199, especially 191.

83. Sermini, Gentile. Novelle, ed. Giuseppe Vettori. Perugia: Avanzini e Torraca, 1968: II, novella 29, $483-$ 496. Discussed in McIver, Katherine A. Kitchens, Cooking, and Eating in Medieval Italy. Lanham: Rowman \& Littlefield, 2017: 74 .

84. From Curnonsky [Maurice Edmond Sailland]. Cuisine et vins de France. Vanves: Larousse, 1953, cited by Hyman, Mary; Hyman, Phillip. Histoire de poissons...: 50.
} 
water fish, but probably salmon, char or perhaps pike-perch would be regarded as the most distinguished. Today, herring remains a fish of almost cult-like devotion in the Netherlands and is well-regarded in Scandinavia, but neither herring nor lamprey enjoy anything resembling their medieval reputation and ubiquity.

In the present environment, with ocean species threatened by over-fishing and river fish by pollution and destruction of habitat, there are efforts to get people to eat little-known or previously rejected varieties. In the United States, a book called American Seafood by a chef named Barton Seaver catalogues over 100 edible fish, mostly unfamiliar, and calls for turning away from the conventional and scarce to the plentiful and unknown. ${ }^{85}$ Resistance to this logical recommendation comes from a preference for the predictable, but also the established hierarchy of fish types. New fish, such as Chilean sea bass, have been introduced, but always on the basis of taste and texture, not on sustainability. We live in enviable times in terms of gastronomic variety, but the ecological conditions and available options of the Middle Ages as regards fish were more favorable than what is available to us today.

85. Seaver, Barton. American Seafood: Heritage, Culture and Cookery: From Sea to Shining Sea. New York: Sterling Epicure, 2017. 